\title{
Isolated liver damage in chemical workers
}

\author{
M DØSSING AND L RANEK \\ From Medical Department A, Division of Hepatology, Rigshospitalet, DK-2100 Copenhagen, Denmark
}

ABSTRACT During a period of 18 months three workers were admitted to hospital with jaundice that had developed two to four months after beginning work at a chemical plant. Liver biopsies showed severe centrilobular, haemorrhagic liver cell necrosis. The pathological changes resolved within six to 18 months. No damage to other organs was observed. The only worker who resumed work at the plant developed clinical and biochemical evidence of relapse of liver damage. Exposure to carbon disulphide, isopropanol, toluene, and acrylonitrile among others was shown, but liver damage may have been caused by a synergistic, hepatotoxic reaction mediated through the hepatic microsomal enzyme system. It was not possible to decide which chemical was responsible.

Occupational liver damage has usually been observed as part of a toxic syndrome dominated by extrahepatic manifestations-for example, central nervous system toxicity related to exposure to trichloroethylene, ${ }^{1}$ xylene, toluene, ${ }^{2}$ DDT $^{3}$; bone marrow depression after exposure to benzene $e^{4}$ and trinitrotoluenes; and peripheral neuropathy due to n-hexane. ${ }^{6}$ Sometimes liver damage is the predominant feature, as in carbon tetrachloride exposure which may also damage the renal and central nervous system ${ }^{7}$; p-tertiary butylphenol toxicity associated with vitiligo and euthyroid goitre ${ }^{8}$; and alcohol intolerance related to dimethylformamide exposure. ${ }^{9}$

Liver injury from industrial agents has only rarely been reported in isolation, ${ }^{10}$ and we therefore discuss the cases of three workers in a chemical plant who were exposed to a variety of chemicals and suggest that liver injury was caused by the combined action of organic solvents.

\section{Clinical features}

All the workers had been healthy in the past, and there was no history of jaundice or gastrointestinal symptoms. None took drugs, and they consumed alcohol only socially. Tests for hepatitis A and B gave negative results.

The time scale of the illness was similar in all subjects. Two to four months after starting work they experienced fatigue, drowsiness, and anorexia; nausea, vomiting, abdominal pain, dark urine, and

Received 4 July 1982

Accepted 29 November 1982 jaundice followed. No patient had fever, pruritus, or clinically detectable enlargement of the liver. Routine and quantitative liver function tests were severely impaired (table). Haematological findings were normal. Judged by creatinine clearance, serum urate concentration, and microscopic examination of the urine, there was no disturbance of kidney function. Clinical signs of pulmonary and cardiac toxicity were absent; results of a chest radiograph and ECG were normal. Neuropsychological tests did not show any cerebral damage, and no patient had experienced dizziness, memory disturbance, lightheadedness, confusion, or visual difficulties.

Jaundice subsided within a few weeks of stopping work and admission to hospital, and liver function tests returned to normal over 18 , four, and four months respectively in the three patients.

The first two patients did not resume work at the plant. The third man convalesced at home and resumed work after six weeks. A few days later he again felt extremely weak with accompanying nausea, abdominal pain, and, eventually, slight jaundice. Blood samples confirmed a return of liver damage with an alanine aminotransferase of $388 \mathrm{IU}$ (normal <40 IU).

\section{HISTOLOGICAL APPEARANCES}

Liver biopsy specimens were obtained at 12,18 , and 16 days respectively after admission in the three patients. Appearances were similar in all, although necrosis was most extensive in the first patient (a woman). They showed severe centrilobular, confluent, haemorrhagic necrosis and in some areas panlobular necrosis but no appreciable fatty change or signs of cholestasis (fig). 
Data from three chemical workers with liver damage

\begin{tabular}{|c|c|c|c|c|c|c|c|c|c|}
\hline No & Age & Sex & $\begin{array}{l}\text { Average daily } \\
\text { alcohol } \\
\text { consumption } \\
\text { (drinks) }\end{array}$ & $\begin{array}{l}s-A L A T^{*} \\
(\text { IU } / 1) \\
\text { (normal } \\
<40)\end{array}$ & $\begin{array}{l}\text { s-alkaline } \\
\text { phosphate } \\
(I U / 1) \\
\text { (normal } \\
<275)\end{array}$ & $\begin{array}{l}\text { s-bilirubin } \\
(\text { Nmol/1) } \\
\text { (normal } \\
<17)\end{array}$ & $\begin{array}{l}\text { Prothrombin } \\
\text { time (arbitrary } \\
\text { units) } \\
\text { (normal } \\
<0.85 \text { ) }\end{array}$ & $\begin{array}{l}\text { Galactose } \\
\text { elimination } \\
\text { capacity (mmol/ } \\
\text { min) (normal } \\
\text { range) }\end{array}$ & $\begin{array}{l}\text { Antipyrine } \\
\text { clearance } \\
\text { ( } \mathrm{ml} / \mathrm{min}) \\
\text { (normal <35) }\end{array}$ \\
\hline $\begin{array}{l}1 \\
2 \\
3\end{array}$ & $\begin{array}{l}44 \\
46 \\
26\end{array}$ & $\begin{array}{l}\mathbf{F} \\
\mathbf{M} \\
\mathbf{M}\end{array}$ & $\begin{array}{l}0 \\
1-2 \\
0\end{array}$ & $\begin{array}{r}2220 \\
576 \\
744\end{array}$ & $\begin{array}{l}486 \\
248 \\
315\end{array}$ & $\begin{array}{r}261 \\
97 \\
266\end{array}$ & $\begin{array}{l}0.34 \\
0 \cdot 57 \\
0.32\end{array}$ & $\begin{array}{l}0.4(1.9-3.6) \\
1.7(2 \cdot 1-3.8) \\
0.9(1.3-3.5)\end{array}$ & $\begin{array}{l}11 \\
32 \\
14\end{array}$ \\
\hline
\end{tabular}

*ALAT = Alanine aminotransferase.

Biopsies were repeated six months after admission. In two patients appearances had greatly improved, leaving fibrotic septa surrounding slightly widened portal tracts. In the first patient the changes were still surprisingly severe, with panlobular necrotic areas and collapse of the reticulin framework. By 18 months, however, histological appearances had returned to normal.

\section{OCCUPATIONAL INVESTIGATIONS}

Because the centrilobular necrosis in the biopsy specimen of the first patient suggested a toxic cause, we obtained an occupational history; at the same time we heard of the third patient who had been admitted shortly afterwards. The first patient, a woman, had worked at home before joining the chemical works. The two men were unskilled and had previously been employed as agricultural labourers. They were all employed in a large chemical plant. The plant supplied chemicals for vitamin synthesis and these patients collected spot samples during the process and analysed these, as well as removing waste products and cleaning laboratory equipment. The chemicals had been used at the plant since 1968 and from then until 198122 workers had been employed.

The first two patients were accidentally exposed to a mixture of carbon disulphide, toluene,

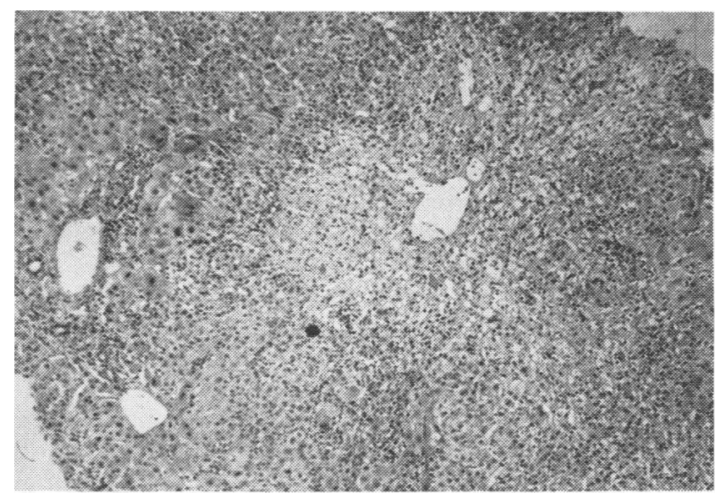

Case 1. Liver biopsy specimen showing severe centrilobular liver cell necrosis with collapse. (Hematoxyline eosine stain $\times 40$ ). acrylonitrile, and methanol. About a week before admission to hospital this mixture had overflowed from a barrel that collected waste solvents from a distillation column. Further exposure was prevented by putting the outlet pipe outside the factory. The workers were still exposed, however, firstly, when they obtained samples to monitor the chemical process, which was done with a mouth pipette at the toluene-acrylonitrile distillation column and, secondly, when they removed waste products from the remaining distillation processes. After the third worker became ill, exposure to all chemicals was minimised by the sealing of waste product outlets, local exhaust ventilation, and the use of cartridge respirators.

Measurements of air concentrations performed with Dräger tubes ${ }^{11}$ during five working days shortly after the first two patients were admitted to hospital showed carbon disulphide concentrations of 3-8 $\mathrm{ppm}$, toluene 15-20 ppm, and methanol 10-150 ppm.

Qualitative mass spectrometry analysis of air samples obtained above barrels collecting hot $\left(150^{\circ} \mathrm{C}\right)$ waste products from different distillation processes showed the presence of 2-(dimethoxymethyl)-propenonitrile, methanol, methylformate, methylacetate, 3-methoxypropenonitrile, isobutanol, 4-amino-2, 5-diethyl-pyrimidine, cyanide, and carbon disulphide. Several unidentifiable substances were also observed.

Liver function tests were performed regularly for six months after measures had been taken to reduce exposure, and no changes were observed. Antipyrine clearance, an index of hepatic microsomal enzyme activity, ${ }^{12}$ was measured during work after occupational hygiene improvements had been carried out and repeated at the end of 10 days; it remained unchanged.

\section{Discussion}

The evidence incriminating chemical substances in the liver damage of these three patients is circumstantial but strong. An identical clinical and histological picture was observed in previously healthy peo- 
ple two to four months after starting work. Hepatic damage recurred in the one subject who returned to work.

The long latent period is similar to that reported for liver injury after exposure to trinitrotoluene, tetrachloroethane, and chloronaphthenes. ${ }^{510}$ Among the chemicals used at the plant, carbon disulphide, acrylonitrile, isobutanol, and toluene are known to be hepatotoxic, but extrahepatic manifestations tend to dominate the clinical picture. ${ }^{21314}$ Cyanide is known to increase the hepatotoxicity of carbon disulphide and was found in the air above the waste of some of the distillation processes. It is also generated by the hepatic microsomal biotransformation of acrylonitrile, and probably during metabolism of the other nitrile containing compounds used at the plant. ${ }^{15}$ Both isopropanol and toluene possess phenobarbitone-like, inducing properties in rats. ${ }^{1617}$ It is therefore possible that the combined action of carbon disulphide, cyanide, nitriles, isobutanol, and toluene may cause liver injury in doses below those that cause extrahepatic symptoms.

Hepatocellular injury with or without fatty change has been reported after long term, continuous or intermittent exposure to relatively low doses of chemicals. ${ }^{18-20}$ In some of these reports it may be asked if the suggested causal relationship between one chemical among many others holds true. ${ }^{18-20}$ Recent animal experiments have shown that one chemical agent may indeed enhance the toxicity of another. ${ }^{21} \mathrm{~A}$ well known example from industry is the synergistic effect of isopropanol on the hepatotoxicity of carbon tetrachloride, probably mediated through an isopropanol-caused stimulation of the microsomal biotransformation of carbon tetrachloride to a toxic metabolite. ${ }^{716}$. From experiments on animals alcohol probably also has a reinforcing effect on the hepatotoxicity of chlorinated hydrocarbons. ${ }^{21}$

These case reports illustrate the difficulties in uncovering causal relationships of disorders in which many chemicals are involved. A careful occupational history should always be obtained in patients with liver disease.

\section{References}

' Grandjean E, Münchinger R, Turrian V, Haas PA, Knoepfel
$\mathrm{H}-\mathrm{K}$, Rosenmund $\mathrm{H}$. Investigations into the effects of exposure to trichloroethylene in mechanical engineering. $\mathrm{Br} J$ Ind Med 1955;12:131-47.

2 O'Brien ET, Yeoman WB, Hobby JAE. Hepatorenal damage from toluene in a "glue sniffer." $B r$ Med J 1971;ii:29-30.

${ }^{3}$ Ensberg IFG, de Bruin A, Zielheuis RL. Health of workers exposed to a cocktail of pesticides. Int Arch Arbeitsmed 1974;32:191-201.

4 Hamilton A. Benzene poisoning. Arch Pathol 1931;11:434-54.

${ }^{5}$ Livingstone-Learmonth $A$. The effects of tri-nitro-toluene on women workers. Lancet 1916;ii:261-9.

- Yamamura Y.n-Hexane polyneuropathy. Folia Psychiath Neurol Jpn 1969;23:45-7.

' Folland DS, Schaffner W, Ginn HE, Crofford OB, McMurray DR. Carbon tetrachloride toxicity potentiated by isopropyl alcohol. JAMA 1976;236:1853-6.

${ }^{8}$ Goldman PJ, Theiss M. Berufsbedingte Vitiligo durch paratertiär-Butylphenol, eine Trias von Vitiligo, Hepatose und Struma. Der Hautarzt 1976;27;155-9.

${ }^{9}$ Lyle WH, Spence TWM, McKinneley WM, Duchers K. Dimethylformamide and alcohol intolerance. $\mathrm{Br} J$ Ind $\mathrm{Med}$ 1979;36:63-6.

${ }^{10}$ Curney $\mathbf{R}$. Tetrachloroethane intoxication: early recognition of liver damage and means of prevention. Gastroenterology 1943;1:1112-6.

"Leichnitz K. Prüfröhrchen-Taschenbuch: Luftuntersuchungen und technische Gasanalyse mit Drägerröhrchen 5th ed. Lübeck, Dräger Werk AG, 1982.

12 Døssing M, Poulsen HE, Andreasen PB, Tygstrup N. A simple method for determination of antipyrine clearance. Clin Pharmacol Ther 1982;32:392-6.

${ }^{13}$ Kubota J. Historical view of carbon disulphide poisoning in the Japanese viscose rayon industry. In: Brieger $H$, Teisinger $J$, eds. Toxicity of carbon disulphide. Proceedings of a symposium, Prague 15-17 September, 1966. Amsterdam: Excerpta Medica Foundation, 1967:192-6.

${ }^{14}$ Sakurai H, Onodera M, Utsunomiya T, Minakuchi H, Iwai H, Matsumura $\mathrm{H}$. Health effects of acrylonitrile in acrylic fibre factories. Br J Ind Med 1978;35:219-22.

is Ahmed AE, Patel K. Acrylonitrile: in vivo metabolism in rats and mice. Drug Metabol Dispos 1981;9:219-22.

${ }^{16}$ Traiger GJ, Plaa GL. Differences in the potentiation of carbon tetrachloride in rats by ethanol and isopropanol pretreatment. Toxicol Appl Pharmacol 1971;20:105-12.

17 Toftgaard R, Gustavson J- $\AA$. Biotransformation of organic solvents. Scand J Work Environ Health 1980;6:1-18.

${ }^{18}$ Willcox WH. An outbreak of toxic jaundice of a new type amongst aeroplane workers. Trans Med Soc Lond 1915;38:129-56.

${ }^{19}$ Mallory TB, Gall EA, Brickley WJ. Chronic exposure to benzene (benzol) III. The pathologic results. J Ind Hyg Toxicol 1939;21:355-93.

${ }^{20}$ Pascale LR, Waldstein SS, Engbring G, Dubin A, Szanto PB. Chromium intoxication with special reference to hepatic injury. JAMA 1952;149:1385-9.

${ }^{21}$ Sato A, Nakajima T, Koyama Y. Effects of chronic ethanol consumption on hepatic metabolism of aromatic and chlorinated hydrocarbons in rats. Br J Ind Med 1980;37:382-6. 